Research Article

\title{
Optimism, Happiness, Life Meaning and Life Satisfaction Levels of the Faculty of Divinity Students: A Multi-Sample Correlational Study
}

\author{
Ali Baltacı ${ }^{1}$ \\ Mersin University
}

\author{
Semra Nurdan Yağlı Soykan ${ }^{2}$ \\ Ankara University
}

${ }^{1}$ Asst. Prof., Mersin University, Faculty of Islamic Sciences, Department of Philosophy and Religion Sciences, 33343 Mersin. Email: alibaltaci@mersin.edu.tr

${ }^{2}$ Res. Asst., Ankara University, Faulty of Divinity, Department of Philosophy and Religion Sciences. Email: snyagli@ankara.edu.tr

Corresponding author:

Ali Baltaci

E-mail:

alibaltaci@mersin.edu.tr

eISSN: 2458-9675

Received: 09.01.2020

Revision: 13.05.2020

Accepted: 23.05.2020

(C)Copyright 2020

by Author(s)

\begin{abstract}
This research was conducted to determine the optimism, happiness, life meaning, and life satisfaction levels of the Faculty of Theology students. Also, within the scope of the research, it is aimed to determine the relations between these concepts. The research was designed as a correlational survey type that is one of the quantitative research methods. The multi-sample group consisted of 943 students studying in the faculties of theology at the universities of Ankara, Istanbul, Marmara, Ondokuz Mays, Ataturk, and Dokuz Eylul. The sample was determined by maximum diversity sampling. "Oxford Happiness Scale Short Form", "Life Orientation Test", "Life Meaning Scale" and "Life Satisfaction Scale” were used to collect data. In addition to descriptive statistics, correlation and hierarchical regression techniques were used to analyze the data. As a result of the research; It was determined that the level of optimism and happiness of the students was medium, whereas the perceptions of life meaning and life satisfaction were low. While women are more optimistic, happy and their life satisfaction is higher than men are, men have more perceptions about the meaning of life than women do. Besides, a significant and positive relationship between optimism, happiness, life meaning, and life satisfaction were determined.

Keywords: Happiness, optimism, the meaning of life, life satisfaction, divinity, student
\end{abstract}

\section{İlahiyat Fakültesi Öğrencilerinin İyimserlik, Mutluluk, Yaşam Anlamı ve Yaşam Doyum Düzeyleri: Çok Örneklemli İlişkisel Bir Çalışma}

\section{$\ddot{\mathrm{O} z}$}

Bu araştırma İlahiyat Fakültesi öğrencilerinin iyimserlik, mutluluk, yaşam anlamı ve yaşam doyumu düzeylerinin belirlenmesi amacıyla yapılmıştır. Ayrıca araştırma kapsamında söz konusu kavramlar arasındaki ilişkilerin belirlenmesi de hedeflenmektedir. Araştırma nicel araştırma yöntemlerinden biri olan ilişkisel tarama türünde tasarlanmıştır. Çoklı örneklem grubu, 2018-2019 öğrenim yılında Ankara, İstanbul, Marmara, Ondokuz Mayıs, Atatürk ve Dokuz Eylül üniversitelerinin ilahiyat fakültelerinde öğrenim gören 943 öğrenciden oluşmaktadır ve maksimum çeşitlilik örneklemesi ile belirlenmiştir. Verilerin toplanması amacıyla 'Oxford Mutluluk Ölçeği Kısa Formu', 'Yaşam Yönelimi Testi', 'Yaşamın Anlamı Ölçeği' ve 'Yaşam Doyumu Ölçeği' kullanılmıştır. Verilerin analizi sürecinde betimsel istatistik analizleriyle birlikte korelasyon, hiyerarșik regresyon tekniklerinden yararlanılmıștır. Araştırma sonucunda; öğrencilerin iyimserlik ve mutluluk düzeylerinin orta seviye olduğu, buna karşın yașamın anlamı ve yașam doyumuna ilișkin algılarının düșük düzeyde olduğu belirlenmiștir. Kadınların erkeklere göre daha fazla iyimser, mutlu ve yaşam doyumları yüksek olduğu, buna karşın erkeklerin yaşamın anlamına ilişkin algıları kadınlara göre daha fazladır. Ayrıca iyimserlik, mutluluk, yaşam anlamı ve yaşam doyumu arasında anlamlı ve pozitif yönlü ilişkiler belirlenmiştir.

Anahtar Kelimeler: Mutluluk, iyimserlik, yaşam anlamı, yaşam doyumu, ilahiyat, öğrenci

Citation: Baltac1, A. \& Yağlı-Soykan, S. N. (2020). Optimism, happiness, life meaning and life satisfaction levels of the faculty of divinity students: A multi-sample correlational study. Spiritual Psychology and Counseling, 5, 167 - 184. https://dx.doi.org/10.37898/spc.2020.5.2.91 
The science, and technology that has developed in the last century have created fundamental changes in individual and social life, and the traditional living that people are accustomed to have been degraded over time. The phenomenon of modernity is criticized in the context of its negative effects as it destroys traditional values, creates radical changes in people's lifestyles, and transforms their psychological states (Kolb, 1986). In daily life, individuals are exposed to the negative effects of modernity at different levels, both socially and individually. This situation creates various areas of pressure and affects their lives negatively (Ferguson, 2005).

The phenomenon of religion, which strives to live and maintain social values and emphasizes tradition by nature, is also affected by the modernity process (Amin, 2006). The mobilization of individuals from rural life to cities for various reasons also affected the visibility and presentation of religion in their living spaces (Subaş1, 2018). The psychology of religion, which examines the interaction between religion and the individual in the social structure, argues that religious elements are also important in preserving the psychological health of the individual by focusing on religious experiences (Ok, 2006). In this context, it is important to determine the psychological health of theology faculty students who will provide religious services to the society in the future. As a phenomenon identified with religion in the public sphere, theology faculties have a privileged position in driving religion to society and keeping it alive. However, the modernity process could influence theology faculties that are considered sacred by society or in an exceptional position. It is essential to examine to what extent the faculty of divinity students internalize the adverse effects of modernity.

In this study, the psychological characteristics of the faculty of divinity students, who have the potential to affect the religious life of almost all segments of society in the future, were examined. The students in question must have a positive psychological life, they can look at life positively and be satisfied and happy with their lives in general. It is also essential that they display an optimistic approach to the problems they face in daily life and have spiritual integrity that can make their lives meaningful and provide satisfaction from their lives. This research focuses on the optimism, happiness, meaning of life and life satisfaction levels of theology faculty students as a phenomenon not yet examined, as far as we know, in the literature of religious psychology and aims to determine the basic characteristics of the students in the context of different variables. It is also aimed to make recommendations to policymakers to improve student qualifications to gain visibility through research. This research will fill an important gap in the literature and provide new and different data for future studies. The most important difference of this study from other studies in the literature is the characteristics of the sample. Students in the study group have had religious education for many years and often qualify as believers or religious people. The study also tries to uncover the link that is thought to exist between positive 
psychology and religious education. In this respect, the hidden goal of the study is to determine the relationship between religion and positive psychology. Besides, the effect of optimism and happiness on life satisfaction and the meaning of life will be examined with the study.

\section{Theoretical Framework}

The science of psychology, which aims to study human nature, has been transformed with the effect of different approaches developed over time and has been affected by developments and changes in positive sciences. In particular, the psychoanalytic approach that Freud pioneered and emphasized the negative aspects of human nature, and the behavioral approach, which had an objective view of man, continued to dominate the science of psychology until the first half of the twentieth century (Seligman and Csikszentmihalyi, 2014). In the rapidly developing psychology with the effect of clinical studies, the insufficiency of the methods focusing solely on mental diseases and attempting to solve the diseases with mechanical methods has emerged and the humanistic approach that claims to solve this deficiency has developed (Eysenck and Keane, 2013).

The humanistic approach emphasizes positive human virtue and designates a human being an innate good, positive, and developable entity (James, 2013). Developing as a new psychology approach that focuses on the positive aspects of human beings since the end of the twentieth century, positive psychology is the study of conditions that help individuals, groups, and institutions to function properly and contribute to their development through methods of psychology (Seligman, 2002). Positive psychology goes beyond the emphasis of classical psychological approaches on diseases and disorders and focuses on psychological health resources (Seligman and Csikszentmihalyi, 2014). In this context, it is aimed to examine the positive orientations of the individual with various topics such as optimism, happiness, wellbeing, spiritual health. In the following section, the concept of happiness, which is an important field of study of positive psychology, will be examined.

\section{Happiness}

Happiness, which is the basic psychological variable that an individual seeks in his or her life, has been handled in various ways historically and intense inquiries have been made about what happiness is and how people will be happy. In general, happiness, which is defined as the state of satisfaction that an individual obtains when he meets his wishes and needs (Csikszentmihalyi, 2013), can be called as the endpoint of human acts or the main purpose of the desires (Argyle, 2013). In the science of religious psychology, happiness is expressed as positive emotion intensity or transcendental effect experienced by an individual (Köse and Ayten, 2012). 
Happiness is defined as an increase in positive emotions (excitement, joy, trust, pride, etc.), a decrease in negative emotions (hopelessness, frustration, anxiety, insecurity, etc.), but it has elements that can be determined as a visible change in pleasure from life (Kahneman, 1999). At this point, the main indicator of happiness is that the individual has negative emotions less and positive emotions more. In this way, one can provide satisfaction from his own life (Seligman, 2002). A happy person is peaceful, cheerful, harmonious with his environment, lively, and energetic; it is also optimistic and productive (Argyle, 2013). In the following section, the concept of optimism will be examined.

\section{Optimism}

In daily life, perceptions of individuals about life events can be altered by the effect of various factors such as personality traits or experiences. While individuals who develop positive attitudes towards the events they encounter in life can deal with problems more easily, a negative perspective can lead to various psychological problems (Ayten, 2012). In this context, optimism has an important place in psychological coping mechanisms (Kaylklık, 2011). Optimism can be expressed as a positive approach to all events and phenomena, a positive attitude, or waiting for the most positive among the options without selecting the specific events and phenomena that individual encounters in his/her life (Hökelekli, 2013; Seligman and Csikszentmihalyi, 2014). Optimism is the result of one's rational expectations, selfefficacy, and the meaning of life (Peterson, 2000).

Optimists are active, dynamic, and action-oriented people. When faced with a problem, they prefer solving it rather than waiting for someone else or ignoring it (Scheier and Carver, 1985). Optimists who have developed problem-solving coping strategies can easily find alternative methods to solve problems (Peterson and Bossio, 1991). Also, optimists, who accept the existing reality more easily, avoid becoming part of the problems they cannot control (Seligman, 2002). Additionally, they do not have great expectations for life and have high self-confidence and can rationally criticize themselves (Snyder and Lopez, 2001). Optimistic individuals, whose communication skills are mostly developed, can establish healthy and longlasting social relationships. They do not focus on the negative side in their thoughts, usually do not engage in friction and do not become involved in conflicts, and lead a psychologically peaceful life (Scheier and Carver, 1985; Snyder and Lopez, 2001).

\section{Life Meaning}

Historically, humanity has questioned what life means, and various disciplines have given various explanations about this question. In general, the meaning of life can be defined as an attempt to shape the purpose of life or to strengthen and 
intensify man's lives (Solomon, 1993). The importance given to living is effective in determining the depth in the meaning of life. Besides, the individual can reach this meaning in life as long as he adopts the search for what life means (Battista and Almond, 1973). At this point, Frankl states that the meaning of life, which includes all individuals in the society and which has no boundaries, cannot be mentioned, and that the meaning of life emphasizes a subjective and dynamic process acquired through learning and experiences for each individual (Frankl, 2018).

The meaning of life is not a phenomenon that can occur at one time, but rather when the concept is defined as a set of awareness and experiences acquired in a particular process, it requires the individual to seek meaning (Zika and Chamberlain, 1992). Although people may not realize it, meaning can be found at every stage of their life and in different forms; however, to capture meaning, an individual must have mental clarity. The meaning of life is the sum of the answers given to different questions like what individuals do and how they achieve goals in their life (Solomon, 1993). The value attributed to these answers also emphasizes the importance of the meaning of life for the individual. Moreover, understanding the underlying causes of different situations in life and establishing a network of different relationships between these situations contribute to the search for meaning in an individual's life (Seligman and Csikszentmihalyi, 2014). Today, it is known that an individual, who lives a fast, dynamic, and active daily life, tries to comprehend the nature of being by pausing in this tempo to capture the meaning of life. The meaning of life is the understanding of the rhythm of the ongoing life and the individual's ability to adapt to this rhythm (Ota and Erricker, 1995). At this point, the meaning of life is often confused with the concept of life satisfaction. In the following section, the concept of life satisfaction will be discussed.

\section{Life Satisfaction}

Satisfaction, which can be defined as the degree to which an individual's expectations, intentions, desires, and needs are met (Peterson, Park, and Seligman, 2005), is an important concept that gives direction to life. Life satisfaction is the difference between the individual's expectations and the degree to which these expectations are met (Diener, Emmons, Larsen, and Griffin, 1985). When the expectations of the individual are compared with the realities in their lives, these expectations either are met or violated (Veenhoven, 1996). Meeting the expectation constitutes life satisfaction, while the violation of the expectation leads to the development of dissatisfaction towards life (Diener et al., 1985).

Life satisfaction emphasizes a psychological situation related to whole life rather than specific situations such as time, place, and opportunity. In other words, even if a person has saturation in a certain place, he may experience dissatisfaction from 
different situations; at this point, it cannot be said that it provides satisfaction from one's life (Argyle, 2013). Life satisfaction is influenced by the individual's experiences, daily life, and future expectations. Besides, the changes that an individual wants to make in his/her life are influenced by the experience of attempts to differentiate his/ her life and the thoughts and behaviors of other people about his/her life (Diener, Lucas, and Oishi, 2002). At this point, many variables such as work-life, leisure time, family and friends' environment, economic conditions, and health status contribute to life satisfaction.

One of the hidden aims of theology faculties is that the religious officials, who will provide religious services to all kinds of people, to have a character that can cope with psychological difficulties. They also must have a certain level of happiness, optimism, the meaning of life, and life satisfaction. In this respect, it is important to investigate the mental health of students of divinity faculties who have the potential to influence society dynamically. Also, the assumption that students should have a positive perspective on themselves, other people they communicate within the environment, and life as a whole is the main source of motivation for conducting this study.

Psychology studies conducted various studies to identify problems that exist or are thought to exist in the individual and take precautions. In most of these studies is that positive psychological feeling of the person's own, it is assumed that it affects their lives. This study focuses mainly on the relationship between religion and positive psychology. It has been tried to test the assumption that people with long-term religious education have a relationship between their education and their positive psychological state. In this respect, it can be determined that the study is a kind of critical psychology study. In this study, it is aimed to test the assumption that happiness and optimism may be related to religion. Besides, concepts such as life satisfaction and meaning of life, which are thought to be influential on the perception of religion, were added to the study. Thus, it was hoped that the interactions between multiple variables would be determined. The main assumption of the research is that the widespread belief that religious education makes the individual happy and optimistic is not valid in practice. Also, it is necessary to examine the pre-acceptance that religion offers a strong meaning of life and satisfaction to people in daily life.

The main purpose of this study is to determine the levels of the positive view of the students of theology faculty towards life. In this context, the students' optimism, happiness, the meaning of life, and life satisfaction levels were tried to be determined. Besides, the relationship between these concepts and the assumption of which demographic variables may be effective in these concepts were also tested. 


\section{Method}

\section{Research Design}

In this study, it has been deemed appropriate to use the quantitative research approach as it is concerned with repeatability, generalizability, and prevalence rather than depth in examining the relationships between variables. This study was designed in the correlational survey model which one of the quantitative research methods. The correlational survey model aims to determine the direction, nature, and intensity of the relationship between at least two variables. In this context, the relationship between the concepts of optimism, happiness, the meaning of life, and life satisfaction among faculty of theology students were focused.

\section{Sampling}

Maximum variation sampling is a purposive sampling technique used to capture a wide range of perspectives relating to the thing that you are interested in studying; that is, maximum variation sampling is a search for variation in perspectives, ranging from those conditions that are view to be typical through to those that are more extreme (Baltac1, 2018; Baran, 2016). For the sample to represent the universe, the faculties in different regions of Turkey are intended to be selected. Six divinity faculties in different regions of Turkey have been selected to provide diversity. The population of the research consists of 6049 students studying in theology faculties of Ankara, Istanbul, Marmara, Ondokuz Mayıs, Atatürk, and Dokuz Eylül universities in 20182019 academic year. The study group of this study consist of 943 students. On the other hand, students studying in these faculties were grouped according to certain qualities, and diversity was created this way. Firstly, gender and class levels were created; Afterwards, layers were arranged to ensure a balanced distribution between each group. In this study, the degree of representation of the sample was calculated as $15.58 \%$. This ratio shows that the basic features of the universe are largely included in the sample. The study group consisted of 452 male and 491 female students. $22.39 \%$ of the participants were 1 st grade, $24.57 \%$ was 2 nd grade, $28.97 \%$ was 3 rd grade and $24.07 \%$ were 4 th-grade students.

\section{Tools}

In the study, a questionnaire consisting of four different measurement tools was used to determine the characteristics of the sample group. It was designed as a sixpoint Likert-type rating (1. Strongly Disagree, 6. Strongly Agree). While the highest score that can be obtained from each scale in the form is six, the lowest score is one. 


\section{Oxford Happiness Questionnaire}

To determine the happiness levels of the sample group, the Oxford Happiness Questionnaire Short Form developed by Hills and Argyle (1987) and adapted to Turkish by Doğan and Çötok (2016) was used. The Cronbach's Alpha internal consistency coefficient of the five-point Likert-type scale, which consisted of one dimension and seven items, was .74. The internal consistency coefficient of the scale used in this study was calculated as .81.

\section{The Life Orientation Test}

Originally developed by Scheier and Carver (1987) and adapted to Turkish by Aydin and Tezer (1991). It is a 12-item self-report survey designed to measure global optimism on a 5 -point scale ranging from strongly disagree (0) to strongly agree (4). The LOT is composed of four positively expressed, four negatively expressed (reverse scored), and four filler items to disguise the purpose of the test that are not included in the scoring. The Cronbach's Alpha internal consistency coefficient of the adaptation form of the scale was .77. The internal consistency coefficient of the scale used in this study was calculated as .84.

\section{Meaning in Life Questionnaire}

The Meaning of Life Scale, developed by Steger, Frazier, Oishi, and Kaler (2006) and adapted by Demirdağ and Kalafat (2015), consists of two dimensions and ten items and it is scored with a five-point Likert-type rating. Cronbach's alpha coefficient of the adaptation form of the scale was .83. The internal consistency coefficient of the scale used in this study was calculated as .86 .

\section{The Satisfaction with Life Scale}

The scale developed by Diener, Emmons, Larsen, and Griffin (1985) and adapted by Dağlı and Baysal (2016) has a one-dimensional, five-question, five-point Likerttype rating. The Cronbach's Alpha internal consistency coefficient of the adaptation form of the scale was .88 . The internal consistency coefficient of the scale used in this study was calculated as .91 .

\section{Data Collection}

The questionnaire was applied carefully by the researchers so as not to interrupt the syllabus of the relevant universities. The sample group was given the necessary ethical information about the research and it was stated that the identity information would not be used within the scope of the research. The necessary practice permits were obtained before the scales were applied. It took approximately 15 minutes for the participants to respond to the data collection booklet, and the scales were 
collected by the researchers. An online questionnaire was created by the researchers to collect the data. This form has been published on the faculty's student groups' email addresses, student communities, and social media. Also, the researchers made it possible for students to fill in the questionnaires by going to the related faculties. Power analysis was performed on the data to make the surveys ready for analysis. In this context, 1019 questionnaires were filled; however, 76 questionnaires which were filled in incompletely and incorrectly were not analyzed.

\section{Data Analysis}

The data were analyzed using the SPSS program. In the evaluation of the findings, the significance level was determined as .05; ANOVA and t-tests were used to examine the differences between the groups. Spearman's Correlation Coefficient was used to determine the interactions between the variables; the absolute value of the correlation coefficient was: 00 - .30 very low, $.31-.49$ low, .50 - .69 medium, .70 - .89 high, .90 - .99 was considered very high interaction (Raykov, 1998). Also, the relationship between the concepts in the study was determined by hierarchical regression analysis. The sixpoint scales used in the study were evaluated in three categories (low, medium and high) and to interpret the weighted average scores: 4.00-6.00 high level (high level of optimism/happiness/meaning of life / high level of life satisfaction), 2, Intermediate level (optimism/happiness/life meaning/life satisfaction) and 0.01-2.00 low level (optimism/happiness/life meaning/life satisfaction) were used.

\section{Findings}

Table 1 shows the participants' optimism, happiness, meaning of life, and life satisfaction levels.

Table 1.

Participants'optimism, life satisfaction, life meaning, and happiness levels

\begin{tabular}{lccc}
\hline Variables & $\mathrm{N}$ & $\overline{\mathrm{X}}$ & $\mathrm{SD}$ \\
Optimism & 943 & 2.28 & .98 \\
Happiness & 943 & 2.23 & .94 \\
Meaning of Life & 943 & 1.95 & .91 \\
Life Satisfaction & 943 & 1.84 & .90 \\
\hline
\end{tabular}

When Table 1 was examined, it was found that the optimism $(\bar{X}=2.28)$ and happiness $(\overline{\mathrm{X}}=2.23)$ levels of the participants were 'moderate; the meaning of life $(\overline{\mathrm{X}}$ $=1.95)$ and life satisfaction $(\overline{\mathrm{X}}=1.84)$ levels were found to be 'low'. Table 2 shows the differences between the variables by gender. 
Table 2.

The levels of optimism, happiness, meaning of life and satisfaction of participants according to gender

\begin{tabular}{|c|c|c|c|c|c|c|}
\hline Variables & Gender & $\mathrm{N}$ & $\overline{\mathrm{X}}$ & $\mathrm{SD}$ & $\mathrm{t}$ & $\mathrm{p}$ \\
\hline \multirow{2}{*}{ Optimism } & Male & 457 & 2,11 & 1.01 & \multirow{2}{*}{2,36} & \multirow{2}{*}{$.009 *$} \\
\hline & Female & 486 & 2,44 & .94 & & \\
\hline \multirow{2}{*}{ Happiness } & Male & 457 & 2,17 & .87 & \multirow{2}{*}{2,29} & \multirow{2}{*}{$.011 *$} \\
\hline & Female & 486 & 2,28 & .91 & & \\
\hline \multirow{2}{*}{ Meaning of Life } & Male & 457 & 1,88 & .99 & \multirow{2}{*}{2,07} & \multirow{2}{*}{$.019 *$} \\
\hline & Female & 486 & 2,01 & 1.09 & & \\
\hline \multirow{2}{*}{ Life Satisfaction } & Male & 457 & 1,78 & .94 & \multirow{2}{*}{3,09} & \multirow{2}{*}{$.001 *$} \\
\hline & Female & 486 & 1,89 & 1.03 & & \\
\hline
\end{tabular}

${ }^{*} p<.05$

In Table 2, there is a meaningful change between the gender and optimism levels of the participants $\left[\mathrm{t}_{(941)}=2,36 ; \mathrm{p}<.05\right]$. According to optimism levels, it was found that males $(\overline{\mathrm{X}})=2.11$ ) had lower levels of optimism than females $(\overline{\mathrm{X}}=2.44)$. The happiness levels of the participants vary significantly according to gender $\left[\mathrm{t}_{(941)}=2,29\right.$; $\mathrm{p}<.05]$. Female participants $(\overline{\mathrm{X}}=2.28)$ had higher levels of happiness than men $(\bar{X}=2.17)$. There is a significant difference between the perception levels of the participants about their meaning of life and their gender $\left[\mathrm{t}_{(941)}=2,07 ; \mathrm{p}<.05\right]$. Male participants $(\overline{\mathrm{X}}=2.01)$ had higher perceptions of the meaning of life than females $(\bar{X}=1.88)$. Life satisfaction levels of the participants vary significantly according to gender $\left[\mathrm{t}_{(941)}=3,09 ; \mathrm{p}<.05\right]$. Female participants $(\overline{\mathrm{X}}=1.89)$ had higher life satisfaction levels than males $(\overline{\mathrm{X}}=1.78)$. Table 3 shows the relationship between the participants' class levels and optimism, happiness, meaning of life, and life satisfaction levels.

Table 3.

Level of optimism, happiness, the meaning of life and life satisfaction of participants according to class level

\begin{tabular}{|c|c|c|c|c|c|c|c|}
\hline Variables & Class Level & $\mathrm{N}$ & $\overline{\mathrm{X}}$ & $\mathrm{SD}$ & $\mathrm{F}$ & $\mathrm{p}$ & Differences \\
\hline \multirow{4}{*}{ Optimism } & Freshman & 229 & 2,43 & .93 & \multirow{4}{*}{3,61} & \multirow{4}{*}{$.013 *$} & \multirow{4}{*}{$\begin{array}{l}1-2,1-3,1-4 \\
2-3,2-4 ; 3-4\end{array}$} \\
\hline & Sophomore & 234 & 2,37 & .85 & & & \\
\hline & Junior & 237 & 2,21 & .98 & & & \\
\hline & Senior & 243 & 2,09 & .87 & & & \\
\hline \multirow{4}{*}{ Happiness } & Freshman & 229 & 2,34 & .90 & \multirow{4}{*}{3,87} & \multirow{4}{*}{$.009 *$} & \multirow{4}{*}{$\begin{array}{l}1-2,1-3,1-4 \\
2-3,2-4 ; 3-4\end{array}$} \\
\hline & Sophomore & 234 & 2,29 & .94 & & & \\
\hline & Junior & 237 & 2,18 & .92 & & & \\
\hline & Senior & 243 & 2,09 & .89 & & & \\
\hline \multirow{4}{*}{ Meaning of Life } & Freshman & 229 & 1,84 & .93 & \multirow{4}{*}{2,92} & \multirow{4}{*}{$.033 *$} & \multirow{4}{*}{$\begin{array}{l}1-2,1-3,1-4 \\
2-3,2-4 ; 3-4\end{array}$} \\
\hline & Sophomore & 234 & 1,89 & .91 & & & \\
\hline & Junior & 237 & 1,99 & .81 & & & \\
\hline & Senior & 243 & 2,06 & .89 & & & \\
\hline \multirow{4}{*}{ Life Satisfaction } & Freshman & 229 & 2,02 & .95 & \multirow{4}{*}{3,02} & \multirow{4}{*}{$.029 *$} & \multirow{4}{*}{$\begin{array}{l}1-2,1-3,1-4 \\
2-3,2-4 ; 3-4\end{array}$} \\
\hline & Sophomore & 234 & 1,91 & .90 & & & \\
\hline & Junior & 237 & 1,77 & .87 & & & \\
\hline & Senior & 243 & 1,69 & .93 & & & \\
\hline
\end{tabular}

$* p<.05$

When Table 3 is examined, it is seen that the optimism levels of the participants 
change significantly with the class level $\left[\mathrm{F}_{(3 ; 939)}=3,61 ; \mathrm{p}<.05\right]$. According to Table 3 , it was determined that the optimism levels of the participants decreased as the class level increased. It was determined that participants' happiness levels changed significantly with the class level $\left[\mathrm{F}_{(3 ; 939)}=3,87 ; \mathrm{p}<.05\right]$. Also according to Table 3 , the happiness levels of the participants decreased as the class level increased. It was determined that the perceptions of the students regarding the meaning of life and their class levels differ significantly $\left[\mathrm{F}_{(3 ; 939)}=2,92 ; \mathrm{p}<.05\right]$. Hence, as the class level increases, participants have a higher level of perception of the meaning of life; that is, the higher the class level, the higher the perception of the meaning of life. It was determined that the participants' perceptions about their class levels and life satisfaction changed significantly $\left[\mathrm{F}_{(3 ; 939)}=\right.$ $3,02 ; \mathrm{p}<.05]$. Therefore, as the class level increases, participants have a lower perception of life satisfaction; that is, the higher the class level, the lower the perception of life satisfaction. The relationship between optimism, happiness, the meaning of life, and life satisfaction levels of the participants are given in Table 4 .

Table 4.

Relationship between optimism, happiness, the meaning of life, and life satisfaction levels of participants

\begin{tabular}{lcccccc}
\hline Variables & $\overline{\mathrm{X}}$ & $\mathrm{SD}$ & 1 & 2 & 3 & 4 \\
\hline 1. Optimism & 2,28 & .98 & - & - & - & - \\
2. Happiness & 2,23 & .94 & $.79 *$ & - & - & - \\
3. Meaning of Life & 1,95 & .91 & $.68^{*}$ & $.72^{*}$ & - & - \\
4. Life Satisfaction & 1,84 & .90 & $.63^{*}$ & $.74^{*}$ & $.81^{* *}$ & - \\
\hline Note: $N=943 ; * p<.01, * p<.05$ & & & & &
\end{tabular}

Note: $N=943 ; * * p<.01,{ }^{*} p<.05$

When Table 4 is examined, it is seen that there is a high-level, positive, and significant relationship between happiness and optimism $(\mathrm{r}=.79 ; \mathrm{p}<.05)$. In other words, the higher the optimism, the higher the level of happiness. There is a moderate, positive, and significant relationship between optimism and meaning of life and life satisfaction (respectively $\mathrm{r}=.68 \mathrm{ve} \mathrm{r}=.63$ ). There is a high level, positive and meaningful relationship between happiness and meaning of life and life satisfaction (respectively $r=.72$ ve $r=.74$ ). Accordingly, the escalation of happiness level increases the meaning of life and perception of life satisfaction. There is a positive, significant, and high-level relationship between the meaning of life and life satisfaction $(\mathrm{r}=.81 ; \mathrm{p}<.01)$. Thus, the increase in the meaning of life increases life satisfaction. Table 5 presents the findings of the hierarchical regression analysis calculated by keeping the level of optimism constant.

Tablo 5.

Hierarchical regression analysis of optimism, happiness, the meaning of life and life satisfaction

\begin{tabular}{ccccccc}
\hline Model & $\mathbf{R}$ & $\mathbf{R}^{2}$ & Adjusted $\mathbf{R}^{2}$ & $\mathbf{R}^{2}$ Change & F Change & $\mathbf{p}$ \\
1 & .79 & .62 & .63 & .63 & 453,248 & .000 \\
2 & .81 & .65 & .65 & .02 & 63,278 & .000 \\
3 & .83 & .68 & .69 & .04 & 20,127 & .000 \\
\hline
\end{tabular}

a: (Constant), happiness

b: (Constant), happiness, the meaning of life

c: (Constant), happiness, the meaning of life, life satisfaction 
As can be seen in Table 5, hierarchical regression analysis of the change of optimism scores was performed in three stages. Firstly, optimism scores were kept constant; happiness in the first step, the meaning of life in the second step, and life satisfaction in the third step were included in the analysis. In the first step, happiness, which had the strongest interaction with optimism, was included in the analysis and this variable explained $63 \%$ of the total variance. The additional contribution of this variable was $4 \%$ and the three variables together increased the total variance in the optimism scores to $69 \%$. As a result; life satisfaction, happiness, and meaning of life variables were found to explain $69 \%$ of the total variance in optimism scores.

\section{Discussion, Conclusions, and Suggestions}

According to the results of this study, which focuses on optimism, happiness, the meaning of life, and life satisfaction levels of theology faculty students, while the participants have moderate optimism and happiness, they have a perception of the low level of life satisfaction and the meaning of life. Although women have more optimism, happiness, and life satisfaction than men. Men's perceptions about the meaning of life are higher than women. Besides, the higher the class level, the lower the levels of optimism, happiness, and life satisfaction. However, the perception of the meaning of life increases with the increase in class level. Plus, a significant and positive relationship was determined between optimism, happiness, life satisfaction, and the meaning of life. It was concluded that the variables of life satisfaction, happiness, and meaning of life explained $69 \%$ of the total variance in optimism scores.

When the results of this research on gender and happiness are compared with the literature, some studies support and contrast the results of this. There are studies in the literature that happiness does not differ in terms of gender (Cihangir-Çankaya, 2009). However, studies are supporting the conclusion that women obtained in this study are happier than men. However, Akın and Şentürk (2012) concluded that men were happier than women. Similarly, the findings suggesting that optimism and genderrelated women are more optimistic than men are supported in the literature and some results contradict this research, also (Ergen, 2016). The finding that men have a higher perception of life meaning than women is supported by different studies in the literatüre (Baş and Hamarta, 2014). Having reached similar results with this research, Taş (2011) found that there was no significant difference between the meaning of life and gender, but that men had higher levels of life than women. On the other hand, Bektas (2012) found that women had more perceptions about the meaning of life than men. The finding that women have more life satisfaction than men, which is evident with this research, is in line with different studies in the literature. However, there are also conflicting results. For example, Elkin (2016) argues that men's life satisfaction is significantly higher. It can also be found in the literature that studies are suggesting that there is no 
significant change in gender and life satisfaction. The reason for the different results in these studies is that the value attributed to the meaning of life is similar for everyone. Although there are physical differences, men and women experience similar emotional states and similarly evaluate life. However, emotion intensity is higher in women than in men, thus women give more meaning to life than men. Women perceive life with their feelings, while men perceive life as a task that should be fulfilled more.

It can be said that happiness, optimism, life satisfaction, and meaning of life levels in theology faculty students are expected to differ according to gender. Because optimism reflects the gender-related characteristics of the meaning of happiness and life. It is known that women internalize events and phenomena deeper than men, and have a more emotional structure and need to reflect their emotionality (Baker, 2012). Also, women are more optimistic about events than men by their nature. In most cases, optimism requires that one's expectations match the rational situation (Hare-Mustin, 1992). When women encounter situations they cannot change, they try to deal with the situation by adopting a more optimistic attitude than men. As the limits of patience and endurance of women are higher than that of men, they tend to the best and show an optimistic behavior system instead of thinking about the worst of the existing situations (Crawford, 2004). Moreover, women's tendency to think positively leads them to better analyze their situations and to be happy even with small positive changes and differences in their lives (Solomon, 1993). However, men are more likely to think about negative situations because they are prone to deal with problem-solving and focus more on the negative aspects of events. Men who are more prone to rational thinking tend to experience happiness only when problems are solved. In this respect, they do not become aware of most situations in their lives or adopt the idea of a constant state of happiness in their lives (Zimbardo and Coulombe, 2016).

The fact that women have more life satisfaction than men can be related to their high level of awareness of responsibility and the high level of pleasure they receive from responsibility (Miller, 2012). It is also known that women can express their feelings more easily and internalize the social roles assigned to them more easily. Women are more easily able to establish social relations with society and their relationship lasts longer than men (Goldthorpe, 1986). Zimbardo and Coulombe (2016) report that women tend to remove men from their living spaces and that women who are more successful in school leave men behind in business. Also, today, women are sufficient for themselves in daily work and can easily access social areas and meet their needs. Besides, women are more productive and prone to living alone than men. However, it can be said that in most cases, men are timider in expressing their emotions, having difficulty in establishing social relationships or being more symbolic in their social relationships, requiring women in meeting some of their needs, and having low satisfaction with life (Seligman and Csikszentmihalyi, 2014; Zimbardo and Coulombe, 2016). 
In the study, it was determined that the students' optimism, happiness, and life satisfaction levels tend to decrease from the first year on. However, the perception of the meaning of life tended to increase during the years students spent at school. This situation reveals that the expectations from university education have changed over the years, and that the students have been making inquiries about the meaning of life in an increasing proportion since the first years and that they have anxiety about the future. Students are optimistic in their early years. Although they have expectations from the future, they hope that this expectation will be met in some way. Over time, expectations are violated and at least some of them are disappointed. Frustrations are the enemy of optimism and allow the optimistic mood to quickly turn into a negative mood (Seligman and Csikszentmihalyi, 2014; Baş and Hamarta, 2014). A similar situation applies to the phenomenon of happiness. In the first years of the students, who are not worried about a prominent future, are happier in their lives. However, in time, they may have to confront reality and give up happiness in the name of the future due to rational choice theory. This rational choice does not mean that there is no happiness. However, these choices emphasize that happiness will be reduced relatively or there will be moments of limited happiness (Pargament, 2002; Argyle, 2013; Seligman, 2002; Peterson, 2000).

Life satisfaction is a highly complex individual process. The satisfaction of the individual's life is possible by balancing the different phenomena that affect his/ her life. In this respect, it can be said that women are more advantageous than men; because women by nature can better internalize order and balance than men (Zika and Chamberlane, 1992; Cihangir-Çankaya, 2009; Taş, 2011). Plus, religious inclinations, doctrines, and worship have an important place in the life satisfaction of the students who receive religious education. Different researches are arguing that religion brings balance to people's lives and helps them to reach an optimistic mood (Peker, 2000; Yapıc1, 2013). Such a positive psychological effect of religion requires that one seek the meaning of life in religious doctrines and that the satisfaction of life must be constructed in the practice of religion itself (Ayten, 2010). Besides, religions create social and psychological support to ensure the happiness of people. In this respect, patience training is conducted in the context of the teachings of pastoral psychology, which is an important field of psychology of religion, and individuals are encouraged to develop positive imagination and use positive religious coping styles (Hökelekli, 2010). However, it is thought that there are different variables such as difficulty in sustaining life, education problems, economic difficulties rather than religious doctrines based on a low level of life satisfaction of theology faculty students who receive a considerable education about spirituality.

In the literature, there is no study yet that deals with all concepts (optimism, happiness, the meaning of life, and life satisfaction) examined in this study. But similar 
studies have been known. Harju and Bolen (1998) found that optimism in university students had a positive relationship with life satisfaction. Güler and Emeç (2006) found a positive and significant relationship between life satisfaction and optimism. Yalçın (2011) determined that optimism in university students is significantly related to life satisfaction. Taş (2011) found a positive relationship between life satisfaction and the meaning of life. Sapmaz and Dogan (2012) inferred that happiness and life satisfaction were positively correlated with optimism.

As a result, it can be said that happiness, the meaning of life, and life satisfaction are related to optimism. Happiness makes the most contribution to this relationship. The reason for this situation can be determined that happiness is effective at every stage of an individual's life and includes dynamic emotional processes that will guide the individual's expectations. In other words, if an individual has an optimistic life, at the same time he is happy with his life, and his life satisfaction increases.

The recommendations developed based on the research results are listed below:

- In this study, optimism, happiness, the meaning of life, and life satisfaction were discussed. In terms of positive psychology, psychological well-being, empathy, and hope, which are thought to be related to each other, can be handled together in different research designs and interdisciplinary studies.

- This research was carried out on the faculty of theology students in different cities in Turkey. It may be recommended to carry out future studies on different groups of the labor market or the public sphere, especially in terms of contributing to the literature.

- This study, in which theology faculty students are examined according to the gender and class variable, can be repeated by adding different demographic or independent variables.

- This study, designed as quantitative research, has certain limitations in itself. Future research must benefit from the detailed nature of qualitative research or the unifying power of mixed research.

- Although an impression of the psychological status of the students is obtained with the research, more detailed determinations are required. The quality of religious education can be increased by determining the psychological qualifications of the students.

\section{Acknowledgement}

Since this study was conducted on the data collected before 2020, the ethical committee approval condition was not sought. However, the working stages comply with the principles set out in the Helsinki Declaration. 


\section{References}

Akın, H. B. \& Şentürk, E. (2012). Bireylerin mutluluk düzeylerinin ordinal lojistik regresyon analizi ile incelenmesi-analysing levels of happiness of individuals with ordinal logistic analysis. Öneri Dergisi, 10(37), 183-193.

Amin, S. (2006). Modernite, demokrasi ve din. İstanbul: Yordam Kitap.

Argyle, M. (2013). The psychology of happiness. New York: Routledge.

Ayten, A. (2010). Dini yönelim boyutlarının kişiliğin beş boyutu ile ilişkisi (amprik bir araştırma). M.Ü. İlahiyat Fakültesi Dergisi, 39(2), 133-148.

Ayten, A. (2012). Tanrı'ya sığınmak: Dinî başa çıkma üzerine psiko-sosyal bir araştırma. İstanbul: İz Yayınc1lık.

Baltacı, A. (2018). Nitel araştırmalarda örnekleme yöntemleri ve örnek hacmi sorunsalı üzerine kavramsal bir inceleme. Bitlis Eren Üniversitesi Sosyal Bilimler Enstitüsü Dergisi, 7(1), 231-274.

Baran, M. L. (2016). Mixed methods research for improved scientific study. New York: IGI Global.

Baş, V. \& Hamarta, E. (2014). Üniversite öğrencilerinde değerler ve yaşamın anlamı arasındaki ilişki. Değerler Ĕ̈itimi Dergisi, 13(29), 369-391.

Battista, J. \& Almond, R. (1973). The development of meaning in life. Psychiatry, 36(4), 409-427.

Bektaş, A. (2012). Yöneticilerin iş tatmini ve motivasyon düzeylerinin yaşam anlamı düzeyi üzerindeki etkisi. (Yüksek lisans tezi, Maltepe Üniversitesi, Sosyal Bilimler Enstitüsü, İstanbul). Retrieved from https://tez.yok.gov.tr/UlusalTezMerkezi/

Cihangir-Çankaya, Z. (2009). Öğretmen adaylarında temel psikolojik ihtiyaçlarin doyumu ve iyi olma. Türk Ĕgitim Bilimleri Dergisi 7(3), 691-711.

Crawford, M. \& Unger, R. (2004). Women and gender: A feminist psychology. New York: McGraw-Hill.

Csikszentmihalyi, M. (2013). Flow: The psychology of happiness. New Haven: Random House.

Dağlı, A. \& Baysal, N. (2016). Yaşam doyumu ölçeğinin Türkçe’ye uyarlanmasi: Geçerlik ve güvenirlik çalışması. Elektronik Sosyal Bilimler Dergisi, 15(59), 1250-1262.

Demirdağ, S. \& Kalafat, S. (2015). Yaşamın anlamı ölçeği (YAÖ): Türkçeye uyarlama, geçerlik ve güvenirlik çalışması. İnönü Üniversitesi Eğitim Fakültesi Dergisi, 16(2), 83-95.

Diener, E. D., Emmons, R. A., Larsen, R. J. \& Griffin, S. (1985). The satisfaction with life scale. Journal of personality assessment, 49(1), 71-75.

Diener, E., Lucas, R. E. \& Oishi, S. (2002). Subjective well-being: The science of happiness and life satisfaction. Positive Psychology, 2, 63-73.

Doğan, T. \& Çötok, N. A. (2016). Oxford mutluluk ölçeği kısa formunun Türkçe uyarlaması: Geçerlik ve güvenirlik çalışması. Türk Psikolojik Danışma ve Rehberlik Dergisi, 4(36), 165-172.

Elkin, N. (2016). Bir aile sağlığı merkezine başvuran yaşlı bireylerde depresyon sıklığı ve yaşam doyumunun değerlendirilmesi. Mersin Universitesi Saglık Bilimleri Dergisi, 9(1), 9-21.

Emeç, H. \& Kümbül-Güler, B. (2006). Yaşam memnuniyeti ve akademik başarıda iyimserlik etkisi. DEUIIBF Dergisi, 21(2), 129-149.

Ergen, Y. (2016). Sinıf ögretmenlerinin sinıf yönetim becerileri, akademik iyimserlikleri ve mesleki bağlılıkları arasındaki ilişki. (Yüksek lisans tezi, Ondokuzmayıs Üniversitesi, Eğitim Bilimleri Enstitüsü, Samsun). Retrieved from https://tez.yok.gov.tr/UlusalTezMerkezi/

Eysenck, M. W. \& Keane, M. T. (2013) Cognitive psychology: A student's handbook. New York: Psychology Press. 
Ferguson, H. (2005). Melancholy and the critique of modernity: Soren Kierkegaard's religious psychology. New York: Routledge.

Frankl, V. E. (2018). İnsanın anlam arayışı (S. Budak, Çev.). İstanbul: Öteki Yayınları.

Goldthorpe, J. H. (1984). Women and class analysis: A reply to the replies. Sociology, 18(4), 491-499.

Gündogdu, M. H. (2010). Life orientations among university students. Egitim ve Bilim, 35(157), 192-199.

Hare-Mustin, R. T. (1992). Making a difference: Psychology and the construction of gender. New Haven: Yale University Press.

Harju, B. L. \& Bolen, L. M. (1998). The effects of optimizing on coping and perceived quality of life of college students. Journal of Social Behavior and Personality, 13(2), 185-200.

Hökelekli, H. (2013). Din psikolojisi. Ankara: Türkiye Diyanet Vakfi.

Hökelekli, H. (2010). Din psikolojisine giriş. İstanbul: Değerler Eğitimi Merkezi Yayınları.

James, W. (2013). The principles of psychology. New York: Read Books.

Kahneman, D. (1999). Objective happiness. Well-being: The foundations of hedonic psychology, $3(25), 1-23$.

Kayıklı, H. (2011). Din psikolojisi: Bireysel dindarlık üzerine. Adana: Karahan Kitabevi.

Kolb, D. (1986). The critique of pure modernity: Hegel, Heidegger, and after. Chicago: University of Chicago Press.

Köse, A. \& Ayten, A. (2012). Din psikolojisi. İstanbul: Timaş yayınları.

Köylü, M. (2013). Türkiye'de yüksek din öğretimi: Nicelik mi nitelik mi? Ondokuz Mayıs Üniversitesi Illahiyat Fakültesi Dergisi, 35(35), 21-44.

Miller, J. B. (2012). Toward a new psychology of women. New York: Beacon Press.

Ok, Ü. (2006). Türkiye'de din psikolojisi: Neredeyiz ve nereye gidebiliriz? Íslami Araştırmalar Dergisi, 19(13), 441-456.

Ota, C. \& Erricker, C. (1995). Children searching for meaning. Resource, 17(3), 2-5.

Pargament, K. I. (2002). The bitter and the sweet: An evaluation of the costs and benefits of religiousness. Psychological Inquiry, 13(3), 168-181.

Peker, H. (2000). Din psikolojisi. Samsun: Aksiseda.

Peterson, C. (2000). The future of optimism. American Psychologist, 55(1), 44-59.

Peterson, C. \& Bossio, L. M. (1991). Health and optimism. New York: Free Press.

Peterson, C., Park, N. \& Seligman, M. E. P. (2005). Orientations to happiness and life satisfaction: The full life versus the empty life. Journal of happiness studies, 6(1), 25-41.

Raykov, T. (1998). Coefficient alpha and composite reliability with interrelated nonhomogeneous items. Applied psychological measurement, 22(4), 375-385.

Sapmaz, F. \& Doğan, T. (2012). Mutluluk ve yaşam doyumunun yordayıcısı olarak iyimserlik. Mersin Üniversitesi Ĕ̆itim Fakültesi Dergisi, 8(3), 63-69.

Saygın, Y. (2008). Üniversite ögrrencilerinin sosyal destek, benlik saygısı ve öznel iyi oluş düzeylerinin incelenmesi. (Yüksek lisans tezi, Selçuk Üniversitesi, Sosyal Bilimler Enstitüsü, Konya). Retrieved from https://tez.yok.gov.tr/UlusalTezMerkezi/

Scheier, M. F. \& Carver, C. S. (1985). Optimism, coping, and health: assessment and implications of generalized outcome expectancies. Health psychology, 4(3), 219-247. 
Seligman, M. E. P. (2002). Handbook of positive psychology. New York: Sage.

Seligman, M. E. P. \& Csikszentmihalyi, M. (2014). Flow and the foundations of positive psychology. New York: Springer.

Snyder, C. R. \& Lopez, S. J. (2001). Handbook of positive psychology. Oxford: Oxford University Press.

Solomon, R. C. (1993). The passions: Emotions and the meaning of life. London: Hackett Publishing.

Subaşı, N. (2018). Öteki Türkiye'de din ve modernleşme. İstanbul: Kopernik yayınları.

Taş, İbrahim. (2011). Öğretmenlerde yaşamın anlamı yaşam doyumu sosyal karşılaştırma ve içdış kontrol odağının çeşitli değişkenler açısından incelenmesi. (Yükssek lisans tezi, Sakarya Üniversitesi, Eğitim Bilimleri Enstitüsü, Sakarya). Retrieved from https://tez.yok.gov.tr/ UlusalTezMerkezi/

Veenhoven, R. (1996). Happy life-expectancy. Social indicators research, 39(1), 1-58.

Vogt, W. P. (2006). Quantitative research methods for professionals in education and other fields. Columbus: Allyn \& Bacon.

Yalçın, İ. (2011). Social support and optimism as predictors of life satisfaction of college students. International journal for the advancement of counseling, 33(2), 79-87.

Yapıc1, A. (2013). Ruh sağllğı ve din. Adana: Karahan yayıncılık.

Zika, S. \& Chamberlain, K. (1992). On the relation between meaning in life and psychological well-being. British journal of psychology, 83(1), 133-145.

Zimbardo, P. \& Coulombe, N. (2016). Man, interrupted: Why young men are struggling \& what we can do about it. Los Angeles: Red Wheel/Weiser. 